\title{
Noget om et halmstrå
}

\author{
ARIS Fioretos
}

\section{En kort indledning}

Mere søgende end systematisk, mere spørgende end påstående, mere beskrivende og iscenesættende end illustrativ og forklarende tenderer essayet - trods sin præcise åbenhed og trods en form for eksakt vaghed

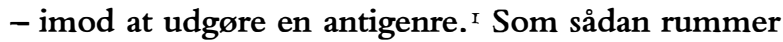
den en længslens poetik, for at tale med Lukács, hvor grænsen mellem det tænkte og det levede, epistemologi og ontologi, udjævnes og fakta og fiktion evner at leve $\mathrm{i}$ hinandens nærhed. Hvis essayisten sejler under et flag må det være usikkerhedens grå. Masten i hvilken han sætter sejl kan i det mindste kun være blyanten, hvis standhaftighed aftegner sig gul og spinkel mod en ellers omskiftelig horisont. I essayets slingrevorne fartøj, så fortrolig med tilværelsens bølger og tidens bratte kast, ja, alt det ustabile i både liv og digt, færdes essayisten på overflader som rummer ligeså mange dybder som lumske grunde. At orientere sig efter idiosynkrasiens indre kompas er hans eneste opgave.

Til denne mærkelige legering af tanke og erfaring, liv og tegn - lad mig kalde den „essayism“ 2 hører evnen til at insistere på fraværet af sikre svar og pålideligt vejrlig. Det kan altså næppe overraske at en slags overlagt perspektivisme, en bevidst stillingtagen gerne anbefales som metode - eller bedre: attitude - for essayisten. Robert Musil skriver for eksempel et sted:

Omtrent som et essay [...] behandler en ting fra mange sider uden helt at fatte den $[\ldots]$ mente han rigtigst at kunne betragte og behandle verden og sit eget liv. 3

Trods sin mangfoldighed af perspektiver, sin bevidste åbenhed og sin strengere form for vaghed lader essayismen sig imidlertid ikke reducere til en løs his- torie eller et klodset forsøg på at fastholde livets konturer på skrift, det vil sige den tilfældige form som en bestemt sekvens af iagttagelser og refleksioner kan skabe når den er blevet læselig. „Oversættelsen af ordet essay til forsøg“, påpeger Musil,

indeholder kun unøjagtigt den væsentligste hentydning til det litterære forbillede; for et essay er ikke det foreløbige eller perifere udtryk for en overbevisning, der ved en bedre lejlighed kunne ophøjes til sandhed [...] et essay er derimod den enestående og uforanderlige form, som et menneskes indre liv antager i en afgørende tanke. 4

I det følgende vil jeg undersøge, hvilken betydning en sådan ,afgørende tanke“ kan have for en forfatter. Tilsyneladende drejer det sig om et kritisk øjeblik med konsekvenser også for den måde man lever på. Den „enestående og uforanderlige form“ som Musil taler om indbefatter i det mindste efter alt at dømme tillige en moral. Essayism er, kort sagt, et spørgsmål om livsholdning. Som eksempel har jeg tænkt mig at tage min Den grå boken, men før jeg begår den fejltagelse at tale nogenlunde for mig selv vil jeg sætte essayet som antigenre $i$ forbindelse med en litteraturvidenskabelig kategori med hvilken den i første omgang synes at have lidet tilfælles, men ved nærmere eftersyn næppe kan klare sig uden: Værket. Det der interesserer mig er relationen mellem essayets fordring om åbenhed og det litterare vans formodede færdighed - eller sagt på en anden mảde: Forholdet mellem igangværende skabelse og arrmgeret produkt, tilblivelse og byrarsing for dé at sted, i den grå zone mellem at blive til co tror jeg at escyoimen har sit mile homon. 


\section{En langere fortsattelse}

I sin egenskab af prøvende medium har essayet en del at gøre med det kasserede, opgivede eller i det mindste det af tankerne forsømte. Men hvis blyantsaffald og viskelædersmuler kunne fortælle om det færdige værk bare en brøkdel af hvad affaldet fortæller om vores liv ville der være grund til at tro på retfærdighed. En sådan veltalenhed er desværre reserveret det „bekymringsløse Elysium“ om hvilket Nabokov engang talte, og der „knækker endda aldrig en pennespids."s Anbragt i en situation som er betydelig mindre paradisisk må forfatteren finde sig $i$ at hans værk kun bliver til et værk når anstrengelserne for at frembringe det ikke længere lader sig $\mathrm{i}$ sigte og indfanges, fikseres eller studeres. Også en ode til viskelæderet, en dityrambe til blyantsspidseren - og hvem har ikke ind imellem drømt om at fæstne den slags hyldester på papir ? - er tvunget til at skjule sliddet bagved stil, beklagelser bagved kunst. Vi siger at et værk som endnu har spor af arbejde (hovedets, men også håndens) ikke har kunnet 'fuldendes', stadig er 'ufærdigt', $i$ alle tilfælde mangler den eneste saliggørende 'finish' og det sidste velsignede 'touch'. Hvorfor kræver det litterære værk disse opofringer af sin forfatter, afsavnene som undertiden bliver registreret, sjældent prist og aldrig gengældt? Hvorfor synes det kun at være lede, svigtende håb og resignation ... undtagelsesvist et anfald af pludseligt mod, men oftest den reneste dumhed ... desperation ... og forfængelighed naturligvis ... som făr os til at opføre os som om vi er blevet 'færdig', som det hedder, når det eneste vi i sandhed kan klare er et liv uden værk?

Fatalt. For at det litterære værk skal kunne blive til må det glemme forfatterens liv - også hvis teksten ikke består af andet end personlige erindringer, private anekdoter og indre erfaringer ... og desuden taler som 'jeg' om 'mig' uden så meget som at blinke. Vi er vant til at adskille især bios og grafe, nogenlunde som vi har knive og gafler i en skuffe, men er vi i stand til at skelne ligeså klart mellem tilblivelse og værk? Den slags størrelser glider ikke fra hinanden som olie og vand hældt i samme skål, men har en tendens til at blande sig ligeså forvirrende let som salt og sukker. Forskellen mærker vi ikke før vi kommer kornene i munden og prøver dem på tungen - og hvor mange læsere gør det når anretningen sjældent endda ser ud til at smage godt?

Ganske vist helligede den kritiske kommentar vurderende eller videnskabelig, subjektiv eller saglig - sig engang det at studere kasserede ordstumper og bortkastede tankespåner omtrent som visse endnu idag kan læse i kaffegrums. Tanken var at denne på alle måder skumle rest udgjorde bundfaldet af et værk, en slags næringsrig psykotop som ligesom en molekylær sekvens indeholdt løftet om det som værket ville blive til. ${ }^{6}$ Undertiden spekulerer jeg på om vores viden om litteraturen $i$ virkeligheden har formået at fjerne os specielt langt fra den positivistiske model og det genetiske historiesyn som her bliver tydeligt og hvis antagelse en fransk tænker engang drev til det yderste da han, med maliciøs elegance, diskuterede den filosofiske værdi i Nietzsches vaskesedler og huskesedler. Værket opstår ikke ud af intet, påpeger de kendere som ikke er bange for et sådant udenomtekstligt stof, men præges af tilblivelsessituationens trefoldige $t$ : tid, tone og temperament. (Føj dertil tiltrækningskraften og dets vogtere har fảet den fjerde musketer som er nødvendig for at forsvare værkets ære som litteratur.) Og naturligvis kan det godt forholde sig sådan. Selv Mallarmés absolutte bog, hvis inderste ønske må have været at befri sig fra kontingensens lænker bærer sporene efter sine omstændigheder ligeså tydeligt som terningen sine øjne.

Alligevel vover jeg at tro at det er forfatterens hemmelige længsel at hindre læserens eftersyn af værkets søm $\mathrm{i}$ at åbenbare et underliggende og egentligere lapperi. At fremstille litteratur med papir, pen og viskelæder, eller tastatur, skærm og ,delete"-tast, er en utaknemmelig proces. Ikke alene spreder det møjsommeligt indsamlede materiale sig i mindst nogle dusin forskellige reminger, men derudover kræver tilrettelægningen af det en i bund og grund guddommelig tålmodighed. (Det er altså lidet overraskende hvis litterære arbejder oftere afbrydes end fuldføres.) Trods forfatterens opfindsomme foranstaltninger til at kunne 'fuldbyrde' værket huserer ydre omstændigheder $\mathrm{i}$ det for det meste som hulrummene i spillet Mikado. Men selv om det værk 
som forfatteren til sidst giver slip på stadig indeholder strittende strå og tråde, af varierende længde og styrke, forskellige slags stoffer og farver, bør det, efter at det $\mathrm{i}$ god behold har forladt hans smertende hænder, i det mindste gøre indtryk af at være sivet ligesom en stor stille plet ved en enkelt rystelse af pennen.

Blandt meget andet indebærer dette at litterære værker må glemme deres oprindelse uden derfor at miste erindringen om sin proveniens. Måske kunne man sige at værket må tage afsked med hånden som skabte det, selv om det bærer dens fingeraftryk ligeså tydeligt som huden sin rødme. (I en vis forstand er hvert værk også en fortabelse - eller, om man vil, en afhændelse.) Dette indebærer at værker faktisk har såvel begyndelse som slutning. Selv de frembringelser som laver numre med parergonale har brug for at holde sig til begge disse poler - om så bare for listigt og lystigt at sætte dem ud af spillet. Hvis værker tror at de kan klare sig uden også sådanne kategorier sørger markedet hurtigt for at de igen pålægges dem. Den strækning som et litterært værk tilbagelægger for at blive til kan med andre ord ikke være uendelig, selv om en forfatter sjældent rigtigt formår at sige hvornår de første anelser om dets tilblivelse virkelig opstod eller altid er helt klar over hvornår det er bedst at tage afsked med værket som med et barn man har ernæret og beskyttet, men som nu viser sig at have udviklet en egen vilje, manier, vaner og - værst af alt - visioner.

Formuleret på denne måde er værkets endelighed med god grund uinteressant. Mere interessant bliver det, tror jeg, hvis vi i stedet for at betragte dets begyndelse og slutning som bios og grafe, eller for den sags skyld tilblivelse og produkt, læser linjen eller den tyndt snoede tråd som forbinder begge poler som fortællingen om en stil - en slags formsprogets egen dannelsesvej, hvor begyndelsen på ingen måde ligger gemt $i$ det første ord og udviklingen $i$ alle tilfælde mere ligner et rynket salathoved end en pænt spolet sytrådsrulle. 7 Her nærmer værket sig hvad vi mener når vi taler om essayet som 'forsøg'. Vi ville da have at gøre med et værk - ingenlunde begrænset til en titel, to bind og nogle hundrede sider hvis linier af bogstaver og interpunktionstegn for- talte en anden historie: Den om eftersøgningen blandt de ord som er blevet skrevet af de ord som endnu vil komme. ${ }^{8}$

Det spændende ved denne linie, fold, tråd, streng - kald det hvad I vil - måske er det forfatterens eneste halmstrå - er at den åbenbarer et værks indvendige uendelighed. Denne udvidelse $\mathrm{i}$ det indre peger ikke længere på en udvikling, vil jeg mene, i hvert fald ikke i positivistisk forstand, men antyder snarere en ind-vikling. Her er ingen evolution, det være sig i stof, skikke eller temperament, men snarere $-i$ de lykkelige tilfælde som forfattere plejer at tilskrive nåden, men $\mathrm{i}$ virkeligheden kun har sætninger og stavelser at takke for - en litteraturens involution. Denne indvortes åbning er den berygtede „verden indeni ordene“, som flere forfattere af kød og blod undertiden taler om, 9 og som en opdigtet poet som John Shade kaldte for en involute abode i sit digt „Pale Fire“.'10 Alene muligheden af en sådan sproglig livsform kan være raison nok for værkets être. Uden videre vover jeg at tro at dette ikke er en mikrokosmisk version af universet, som det alt for ofte antages af også de bedrevidende. Verdensaltet lader sig ganske vist spejle $i$ en vandpyt, men hvilke galakser ville den der forsøgte at undersøge en blækklat få at se?

Til ejendommelighederne ved værkets indre uendelighed hører at denne udvidelse ikke sikres gennem den litterære mønt som forfatteren i bedste fald får held til at slå på en vis tematisk kapital. Blækudgydelsen jeg taler om kan være tynd som natgammel is, folde sig ud som en blomst og skrumpe som en lever, undertiden er den stille og sej som ukrudt, undertiden er den uregerlig og løbende som æggeblomme, men $\mathrm{i}$ ingen af tilfældene beror dens virkning på os på andet end forfatterens fornemmelse for stilhed, opbygning og idiosynkrasi, rytme, komplikationer og overraskelse... samt naturligvis den grænseløse tiltro til en storslået upålidelighed.

Den eneste (nødvendige men ikke tilstrækkelige) garant for at et værk skal åbne sig indad er måden på hvilken stavelserne sættes sammen med hinanden, afstanden mellem ordene trækkes til, sætningerne snører sig sammen og afsnittene derefter forbindes med hinanden, det ene efter det andet, indtil 
alt er blevet til et svævende væv af nuancer som ikke engang tarveligt anbragte modhager eller indvendinger af den mere gemene slags er $i$ stand til at trævle op - for alt består nu af den gennemsigtigste, utydeligste hinde af forbindelser. Men nej, for i det mindste at rydde den misforståelse af vejen: Dette er ikke et billede på den $\mathrm{i}$ de senere år så feterede „tekst“, værkets formodede modstander, men på det net som ethvert værk kaster over liv og digt og som gør disse kategorier, anede gennem forbindelsernes garn, uskarpe i konturerne. This / Was the real point, betoner Shade i sit digt, the contrapuntal theme:

Just this: not text, but texture; not the dream

But topsy-turvical coincidence,

Not flimsy nonsense, but a web of sense.

Yes! It sufficed that I in life could find

Some kind of link-and-bobolink, some kind

Of correlated pattern in the game,

Plexed artistry, and something of the same

Pleasure in it as they who played it found. ${ }^{\text {II }}$

Kun når forfatteren med fletværkets artisteri væver det correlated pattern som bliver til et værk kan læserens tanker hvirvle ind mod den elastiske tomhed på den måde vi alle skal engang. Mønster og ikke monstrum holder opmærksomheden ved lige. Kort sagt: Værkets indre uendelighed beror ikke på hvad tegnene som det indeholder muligvis betyder, men på den (undertiden eventyrlige) måde på hvilken de gør det. Måske er det denne omstændighed der gør at essayet, antigenren par excellence, og således, først, mindst af alt et „værk“, alligevel er underlagt så strenge formkrav.

At det mærkelige fald ind mod den gennemsigtige verden inden $i$ ordene til stadighed lader sig gentage på ny når vi læser - og kun sådan forbliver Shades involute abode lige så uendelig vid som grænseløst generøs - skyldes i alle tilfælde værkets mirakel. Sådan er det altid tilgængelige nu som ethvert sindrigt foldet mønster skaber. Og følgelig er det at skrive det samme som at lære at gå på vandet. I en anden bog, kaldet Transparent Things, påpeger Nabokov:
En tynd hinde af umiddelbar virkelighed ligger over naturligt og opfundet stof, og den som vil blive i nuet, med nuet, nu, må være sød ikke at bryde dens overfladespænding. Ellers vil den uerfarne mirakelmager opdage at han ikke længere går på vandet, men synker oprejst blandt stirrende fisk. ${ }^{\mathrm{I2}}$

\section{Og en kort afslutning}

Det der sker når man bryder denne hinde er, tror jeg, hvad der sker i Den grå boken. ${ }^{13}$ Men i stedet for at skabe den enlige blækklat som jeg nu har omtalt to-tre gange og som jeg har lånt fra en tekst af William Gass, ${ }^{14}$ formede min udgydelse sig snarere som en sky af bly. Langsomt sank jeg stadig dybere ned i en lomme af den mest rummelige ro, den blideste fred - og slog mig hårdt.

Hensigten var imidlertidat gå ud fra en af litteraturhistoriens mere slidte klichéer - det dødsøjeblik i hvilket billeder fra ens liv passerer revy og udvinde en slags friskhed fra den. Hvis man foretrækker det så var dette for mig den ,afgørende tanke“" om hvilken Musil talte. Jeg ville skrive et essay som handlede om essayets betingelser. Det der skulle gøre det „unik“ og „uforanderlig“ i formen, havde jeg tænkt mig, var altså at det skulle tage essayets måde at betyde på som sit udgangspunkt, det vil sige lade form blive til indhold. Det siger sig selv at denne hensigt voldte en del problemer, eftersom også metaessays stiller formelle krav. Men ud af den mulige diskrepans mellem det der blev omtalt og det der samtidigt blev fremstillet, den grå zone mellem udsigelsen og det sagte, håbede jeg at essayismens vilkår alligevel ville blive tydelige.

Startsignalet til arbejdet fandt jeg hos Rilke - i en passage $\mathrm{i}$ begyndelsen af optegnelserne om Malte Laurids Brigge (som oprindelig ikke blev taget med $i$ bogen, men som nu er blevet indarbejdet $i$ den omeller snarere nyskrevne amerikanske version). „Hvordan kunne denne lille grå kvinde“, hedder det,

dengang fă den idé at stå ved siden af mig foran et udstillingsvindue $\mathrm{i}$ femten minutter, alt imens hun viste mig en lang gammel blyant som uendeligt langsomt skød frem fra hendes elendige, knyttede hænder? Jeg lod som om jeg betragtede de udstillede ting og ingenting bemærkede. Men hun vidste at jeg 
havde set hende, og forsøgte at blive klar over hvad hun egentlig foretog sig. Thi at det ikke kunne være et spørgsmål om blyanten forstod jeg naturligvis; jeg følte at det var et tegn, et tegn for de indviede, et tegn som de udstødte kender til; jeg fornemmede at hun gjorde tegn til mig om at komme med et sted hen eller gøre noget. Og det mærkeligste var at jeg hele tiden ikke kunne blive fri fra følelsen af at der faktisk må findes en vis aftale som dette tegn hørte sammen med og at denne scene $i$ bund og grund var noget jeg burde have ventet mig. ${ }^{\text {Is }}$

For mig begyndte arbejdet med bogen der, i scenen med den lille grå kvinde som gådefuldt skyder en gul (gættede jeg mig til) blyant frem fra sine krampagtigt knyttede hænder. Et signal, det var alt, „som de udstødte kender til“ og som åbnede en usikker zone mellem fagter og indhold, gestus og betydning, i ... ja, også det ... fordærvets tegn.

Hvad jeg derefter gjorde, eller forsøgte at gøre, var at lede efter eksempler på den form for præcis vaghed som Rilkes blyant forekom at varsle. På en eksakt måde syntes den ikke at være beregnet til noget særligt. Min opmærksomhed blev, kort fortalt, fanget af hvorledes vaghed betyder og langsomt begyndte jeg at indsamle det som Benjamin i sin artikel om Kafka kaldte for ,skyede steder“. ${ }^{16}$ Fra biblioteksterminologien hentede jeg fagudtrykket ,grå litteratur“ $\mathrm{i}$ forhåbningen om at det kunne dække, eller $\mathrm{i}$ det mindste indtegne det nebuløse område som jeg mente jeg var stødt på. Konventionelt anvendes termen til at beskrive materiale som har et begrænset oplag og distribueres udenfor de sædvanlige kanaler: Forretningsrapporter, specifikationer af teknisk art, referater fra konferencer, diplomatiske forsendelser og lignende - det vil sige tekster der er instrumentelle $\mathrm{i}$ deres karakter og derfor mangler den type overskud af betydning som normalt forbindes med litteratur. I en håndbog som jeg stødte på blev den ,grå litteratur“ imidlertid også betegnet som ,en indikator på tvivl, vaghed og manglende præcision“. ${ }^{17}$ En beskrivelse som $\mathrm{i}$ mine øjne lige så godt kunne karakterisere det der skete i scenen mellem Malte og den gamle kvinde foran et udstillingsvindue i Paris. For mig indebar denne „viser“ eller indicator - denne, hvorfor ikke, forlæn-gede pegefinger $-i$ hvert fald at det blev muligt at omdefinere termen og lade den henvise til det flygtige, uhyggelige og hensmuldrende $i$ en vis type litteratur - thi forsvindingen, vidste jeg, var den mærkelige sol som min tankeverden bevægede sig omkring.

I spørger hvad denne redegørelse har at gøre med mere overlagte tanker omkring det som jeg har kaldt essayism? Ikke meget. I særdeleshed ikke eftersom tilintetgørelsen vitterligt kan være en Beatrice, $\mathrm{i}$ hvert fald hvis vi skal tro Mallermés brev til vennen Léfebure, ${ }^{18}$ mens forsvindingen næppe nogensinde kommer til at føre en forfatter til paradis. (Så skulle det da lige være til de evige jagtmarker.) Men lad mig vende tilbage til Nabokov og den bog i hvilken han måske dygtigst væver en hel historie omkring et forsvindende øjeblik, stort set ikke større end spidsen af en blyant, men alligevel mere rummelig end den største slags sæk. I begyndelsen af Invitation to a Beheading fortæller han om den dødsdømte Cincinnatus C., som ,drømte at han gik på vandet“ og kun har en mulighed for at overleve:

På bordet glimtede et tomt ark papir og tydeligt aftegnet mod denne hvidhed lå en fint spidset blyant, så lang som et hvilket som helst menneskes liv (bortset fra Cincinnatus) og med et skær af ibenholt spillende over hver eneste af sine seks sider. Et oplyst afkom af pegefingeren. Cincinnatus skrev: „Trods alt er jeg forholdsvis. Når det kommer til stykket havde jeg forudanelser, forudanelser om denne afslutning." "I

Dette er en i mange henseender mærkelig passage, ikke mindst fordi den står $\mathrm{i}$ begyndelsen af bogen men taler om en afslutning. Nabokovs bog begynder så at sige med at slutte. Det der hænder i den er en afhændelse. Den eneste mulighed som hans helt har for at overleve er at gøre brug af pennen på bordet foran sig. Så længe han skriver kan han ikke være død. En mere ,afgørende tanke“ er i alle tilfælde svær at forestille sig. Her er næppe mulighed for at komme ind på hvordan Nabokov udvider dette øjeblik til at omfatte et helt liv. Men han gør det på en måde som til sidst făr det til at fremstå som om værkets indre rummer dets ydre - og det er, tror jeg, i sidste ende enhver forfatters drøm. Som læsere kigger vi ind $\mathrm{i}$ bogen som ind $\mathrm{i}$ den fængselscelle hvor Cincinnatus sidder, gennem et kighul, der 
minder om en læk i en båd, og det er ikke underligt at helten bliver tvunget til at indse:

$\mathrm{Nu}$ mister jeg den tråd som jeg så håndgribeligt holdt fast i for et øjeblik siden. Hvor er den? Den er gledet mig af hænde. Jeg kryber skælvende sammen over papiret, tygger på pennen indtil jeg når ind til blyet, bøjer mig fremad som for at gemme mig for døren gennem hvilken et skarpt øje stikker mig i nakken. ${ }^{20}$

Den grå boken forsøgte at markere dette kighul takket være hvilket yderverdenen siver ind $\mathrm{i}$ værkets indre ved på titelbladet at lægge initialerne til Cincinnatus navn på siden, næsten som om at den allerede havde opgivet håbet om en fortsættelse, og derefter indskrive forkortelsens efterfølgende punkt i dets åbne indre: $U$. Sådan kom den middelalderlige typografis tegn for „de steder hvor et svært eller dunkelt spørgsmål ikke kan åbnes eller løses“2I - det såkaldte cryphia - til at skabe den figur $\mathbf{i}$ hvis tegn bogen ville blive læst. Hvis det omkuldvæltede bogstav stod for værkets ydre aspekt, et ydre som nu langsomt var på vej til at lukke sig og 'fuldbyrdes', så stod prikken i dets midte for dets indre, et svævende hjerte som vel nærmest svarede til det springende punkt som Cincinnatus liv endnu udgjorde. ${ }^{22}$

Håbløse forfattere. Hvilke forviklinger. Er dette ikke indbildskhed og fantasi? Lyt til Cincinnatus igen:

Jeg skræller lag efter lag af, indtil endelig...jeg ved ikke hvordan jeg skal beskrive det, men dette ved jeg: Gennem en proces af gradvis afhændelse når jeg til sidst det endegyldige, udelelige, faste punkt, og dette punkt siger: Jeg er! Ligesom en perle beskyttet af en hajs blodige fedt - $\mathrm{O}$ mit evige, mit evige ... og dette punkt er tilstrækkeligt for mig - faktisk er intet andet nødvendigt. ${ }^{23}$

Med lidt god vilje håbede jeg at den abstruse figur på titelbladet til min bog også kunne læses som spidsen af en blyant set forfra, og da, forestillede jeg mig, kunne den rumme vinket om den eneste redning som er en forfatter til dels hvis han vil holde sig flydende og i live. Dette gule værktøj, fra hvilket den indviklede beretning om hans stil bliver til, er forfatterens eneste halmstrå. At sætte det til og på papiret (valget af præposition er umuligt at træffe) gør han kun med visheden om at dets skrift udgør „en proces af gradvis afhændelse.“ Sådan er moralen, om man vil. Kald det essayism - eller det indbildske forsøg på at overleve.

„Et halmstrå?““, bemærkede Kafka i et sent notat som jeg læste:

Nogle holder sig oppe over vandet med en blyantstreg. Hvad er det at holde sig oppe? Drømmer som den druknende om redning. ${ }^{24}$

På dansk ved John Bang Jensen 
Noter

I. Jeg følger her Thomas Harrison. Se Essayism: Conrad, Musil, and Pirandello (Baltimore: The Johns Hopkins University Press, 1992), side 3.

2. Jeg låner termen fra Harrisons udmærkede plaidoyer. (For de følgende to Musil-citater, se Essayism, side 2 og 34.)

3. Der Mann ohne Eigenschaften, Gesammelte Werke, udgivet af Adolf Frisé (Reinbek: Rewohlt, I978) I. del, side 250. [Manden uden egenskaber, ovs. af Karsten Sand Iversen, bd. I s. 269].

4. Der Mann ohne Eigenschaften, side 253. [Da. ovs. bd. I s.272].

5. "The Vane Sisters“, The Stories of Vladimir Nabokov (New York: Knopf, 1995), side 6r8.

6. Nicholson Baker har parodieret denne drift $\mathrm{i}$ et kort stykke med titlen „Mlack“ (nu indføjet i The Size of Thoughts: Essays and Other Lumber [New York: Random, I996], side II7-II8). I stedet for at slette slåfejl, dårlige formuleringer og mislykkede betydningskonstruktioner skubbede han dem en dag længst ned på skærmbilledet. Sådan opstod der en på sin egen måde læsværdig bagvendt parodi på en arbejdsdags forfejlede anstrengelser.

7. Dette er naturligvis en variation over Nabokovs kvikke iagttagelse at ,den bedste del af en forfatters biografi ikke er redegørelserne for hans oplevelser, men beretningen om hans stil“" (Strong Options [New York: Vintage, 1990 (1973)], side I54-I55) - en tese som Joseph Brodsky senere skærpede ved at fremholde at ,en forfatters biografi ligger $\mathrm{i}$ hans sprogs vendinger" (i titelstykket i Less Than One: Selected Essays [New York: Farrar Straus Giroux, I986] side 3).

8. Jeg låner en iagttagelse af William Gass. Se „Preface“, In the Heart of the Heart of the Country (Boston: Godine, I989 [1968]) side xxv.

9. For eksempel - naturligvis - endnu engang - William Gass. Jæunfør The World Whitin the World (New York: Knopf, 1978).

ro. Vladimir Nabokov, Pale Fire, (New York: Vintage, I989 [1962]), side 63, linierne 8I7-8I8.

II. Pale Fire, side 62-63, linierne 806-8I5.

I2. Transparent Things (New York: Vintage, I989 [1972]), side 2.

I3. Måske kunne man sige at bogen vil lade vendingen fra betyning til betydende, fra sagt til udsigelse, vrides endnu en omgang og dermed gøre måden på hvilken litteratur kan betyde til sit indhold. Naturligvis er det en opgave som er dømt til at mislykkes.

I4. „Preface“, In the Heart of the Heart of the Country, side xxxiii.

I5. Aufzeichnungen des Malte Laurids Brigge, Sämtliche Werke, udgivet af Rilke-Archiv (Frankfurt am Main: Insel, 1976 [I955]), 2. del, side 7I7.
I6. „Franz Kafka. Zur zehnten Wiederkehr seines Todestages“, Gesammelte Schriften, udgivet af Hermann Schweppenhäuser och Rolf Tiedemann (Frankfurt am Main: Suhrkamp, 1974- 1989), del 2:2, side 427.

I7. C. P. Auger, Information Sources in Grey Literature, anden udgave (London: Bowker-Saur, I989) side viii.

I8. Se Correspondance, udgivet af Henri Mondor og JeanPierre Richard (Paris: Gallimard, 1959), I. del, side 246. I9. Invitation to a Beheading (New York: Vintage, I989 [1959]), side I2-13. 20. Invitation to a Beheading, side 9I.

2I. his locis ubi quaestio dura et obscura aperiri uel solui non potuit. Isidorus fra Sevilla, Libri etymologiarum (1386), I. del, side xxi. Citatet fra M.B. Parkes, Pause and Effect: Punctuation in the West (Berkeley: University of California Press, I993), side I73.

22. Og som Ekelöf, i en mindeværdig gestus, udpegede på sit dødsleje. „Ved halvto-tiden om natten“, hedder det $\mathbf{i}$ En självbiografi, „efter urolig søvn, hvor G. talte meget men uhørligt, beder om vand, ændrer det til pennen, knapper pyjamasskjorten op, føler med den ene hånd ud efter ribbenene, peger derefter med pennen på hjertet og siger 'det her er hjertet'. Taler derefter utydeligt, virker rolig, saglig.“ Så tilføjer Ingrid Ekelöf: „Slumrer siden ind, bliver pludselig meget bleg, åndedrættet forandres, efter kort tid er han død. Tilsyneladende roligt. „En självbiografi, udgivet af Ingrid Ekelöf (Stockholm: Bonniers, I97I), side 300. Her ville en anerkendende hilsen til Magnus William-Olsson være på sin plads. I et endnu upubliceret foredrag beskæftiger han sig indgående med dette tekststykke.

23. Invitation to a Beheading, side 90 .

24. „Fragmente aus Heften und losen Blättern“, Hochzeitsvorbereitungen auf dem Lande, Gesammelte Werke, udgivet af Max Brod (Frankfurt am Main: Fischer, 1983), 6. del, side 280. 